\title{
Influence on Student Academic Behaviour through Motivation, Self-Efficacy and Value- Expectation: An Action Research Project to Improve Learning
}

\author{
Hallgeir Nilsen \\ University of Agder, Department of Information Systems, \\ Kristiansand, Norway
}

Hallgeir.Nilsen@uia.no

\begin{abstract}
Pedagogic research has found that motivation, self-efficacy and value-expectancy are the most influencing factors on student academic behaviour (Bandura, 1997; Linnenbrink \& Pintrich, 2002), which again are heavily influenced by how students experience success, confidence and well-being, lecturers motivation and enthus iasm, and how theory and practice is tied together. Universities will increase, maintain, or decrease motivation, self-efficacy, and value-expectancy. The author believes that in order to increase student learning universities need more focus on and more use of pedagogical knowledge, to even more positively influence student academic behaviour. Through implemented actions and interviews of bachelor students in IT and information systems, valuable information is collected on what influences motivation, self-efficacy, and value-expectations. The good news is that by simple means we can more likely have students that experience success, are confident and well-being, and who see the value in what they work on, which in turn will influence academic behaviour and academic success.
\end{abstract}

Keywords: academic behavior, motivation, self-efficacy, expected-value, learning.

\section{Introduction}

In the bachelor program in IT and information systems at University of Agder (UiA) we have had a drop out rate up to more than $60 \%$ during the three year program. On this background a project was started to find the reason for drop out and implement actions to increase learning and reduce the dropout rate among our students.

According to a survey carried out among bachelor students in Information Systems at UiA, lack

Material published as part of this publication, either on-line or in print, is copy righted by the Informing Science Institute. Permission to make digital or paper copy of part or all of these works for personal or classroom use is granted without fee provided that the copies are not made or distributed for profit or commercial advantage AND that copies 1) bear this notice in full and 2) give the full citation on the first page. It is permissible to abstract these works so long as credit is given. To copy in all other cases or to republish or to post on a server or to redistribute to lists requires specific permission and payment of a fee. Contact Publisher@InformingScience.org to request redistribution permission. of motivation, mismatch between expectations and content in the study programme in addition to ineffective studystrategies were the most important reasons for dropping out (Nilsen, 2006).

Since motivation, self-efficacy, and value-expectancy are the most influencing factors on students' academic performance (Bandura, 1997; Linnenbrink $\&$ Pintrich, 2002), these constructs and 
the mechanisms behind them need a thorough understanding. Then actions aimed at influencing motivation, self-efficacy and value-expectancy can be implemented. This is what the rest of this paper is about.

\section{Background}

I started working at the University of Agder (UiA) in 1997 after ten years in consulting, because I wanted to teach and to work with students. The first years I did a lot of teaching and partic ipated in several projects, which I really enjoyed. In addition I did some research, which I mostly liked. What I struggled with was academic writing. At this time our school applied to be a full university, with much focus on research and publishing. I found when I was "pushed" to publish, to produce a certain number of publications, it reduced my motivation and joy in my work. After some negative feedback I started to believe I could not write academic papers.

Then I decided to follow my intrinsic motivation, to focus on the things that were the reason for me to be at the University. I asked myself about my job: Why do I work at a University, - what gives me meaning? The answer was the same as my initial reason for entering the University, namely to work with students. The last two years I have worked almost $100 \%$ with studentrelated tasks: teaching, implementing actions to increase motivation and decrease dropout rate, and to learn more about student motivation. The work with students has inspired me to undertake research on student motivation; I have even published some of it. Publishing is not a goal, but a result of work I find interesting and valuable.

My motivation and commitment at UiA was in the beginning very high, then lower, and now increasing, because I now do what I believe is important. I enjoy my work more and believe I contribute to something important. This made me think of our students. When I was an Associate Professor, with a high degree of freedom and possibilities to influence my own work, I lost much of my motivation; how is it then for our students?

When someone enters a job or a study program, they will mostly be motivated because of expectation of a new situation. Let's assume students that enter our bachelor program in Information Systems are motivated and, hopefully, mostly intrinsically motivated. This motivation may be based on unrealistic or wrong expectation, but nevertheless, let's assume most students that enter the program are motivated.

But it seems like this initial enthusiasm disappears for many students. Some researchers suggest "something or someone is decreasing the high levels of motivation" that students and employees bring with them to the classroom and workplace (Bowman, 2007; Sirota, Mischkind, \& Meltzer, 2005). Instead of asking how we can motivate students we could ask "how educators can be deterred from diminishing — even destroying — student motivation and morale through their policies and practices?" (Bowman, 2007; Sirota et al., 2005) The key question then is, "How can lecturers maintain student's initially high motivation?"

The goal in my work at UiA is to maintain and increase motivation, self-efficacy and valueexpectations among bachelor students in IT and Information Systems. Interviews of first and second year students in fall 2007 and 2008 have given valuable information and a deeper understanding of the mechanisms behind motivation, self-efficacy, and value-expectations.

\section{Motivation}

Motivation is identified as a fundamental aspect of learning (Brewer \& Burgess, 2005). But what is motivation really, how do I know I am motivated? "To be motivated means to be moved to do something" (Ryan \& Deci, 2000). Excitement, interest, and enthusiasm towards learning are the primary components of motivation (Crump, 1995). 
People do not only have different degrees of motivation, they also have different kinds of motivation. Level of and orientation of motivation will vary according to situation. Motivation will lead to actions; specifically, motivation to learn is characterized by long-term involvement in learning (Ames, 1990).

\section{Intrinsic and Extrinsic Motivation}

Self-Determination Theory (Ryan \& Deci, 2000) distinguishes between different types of motivation based on the different reasons or goals that give rise to an action. The most central distinction is between intrinsic motivation and extrins ic motivation.

Intrinsic motivation is the tendency to engage in tasks because one finds them interesting and enjoyable. Students with more intrinsic motivation tend to persist at difficult problems and learn from their mistakes (Walker, Greene, \& Mansell, 2006). In addition, intrinsic motivation is central for the integration process through which elements of one's existing internal knowledge is integrated with new knowledge.

Extrinsic motivation is the tendency to engage in tasks because of task-unrelated factors such as the expectation of reward or punishment, for example ,to pass the exam or get a good grade (Vansteenkiste, Lens, \& Deci, 2006).

We differ in our general tendencies to be intrinsically or extrinsically motivated. But our intrinsic and extrinsic motivation will also vary over situation and time (Moneta, 2004).

It is documented that intrinsic motivation will influence student behaviour in a positive way (Miller, 1988). Students who are intrinsically motivated to perform a task will usually be more self-regulated, they can work concentrated over time and use a repertoire of strategies to manage challenges. The state that comes into being when mastery is a result of hard work and concentration is called "flow". Skills, activity, and perceived challenge of the activity are important to achieve flow. Flow may be seen as the ultimate self-regulated learning. Through "flow" the ability to concentrate and perform is very much enhanced (Csikszentmihalyi, 1990)

The division into surface and deep learning is another way to describe how students approach learning (Honkimaki, 2004). Students applying a deep approach try to integrate new information with existing knowledge; the focus is on understanding what they are studying. In the surface approach, the student is driven more by an extrinsic motivation, with the aim of mainly passing examinations. A student deploying a surface approach typically tries to memorize details without trying to construct an integrated know ledge base.

\section{Self-efficacy}

Perceived self-efficacy is defined as people's beliefs about their own capabilities to perform. Bandura has written several articles on self-efficacy. "People's judgments of their capabilities to organize and execute courses of action required to attain designated types of performances" (Bandura, 1977). Distinct from efficacy, which is the ability to produce an effect, self-efficacy is the belief that one has the ability to perform.

People will be more positive about working on a task if they believe they can succeed. People will avoid or reduce the energy into tasks if they believe they will not succeed. On the other hand with high self-efficacy, where we believe we can succeed, we will put in more energy in order to succeed.

Self-efficacy significantly beyond one's own ability may lead to a tendency to overestimate one 's own ability to complete tasks, which can lead to failure and reduced self-efficacy. On the other hand, self-efficacy significantly lower than one's own ability may lead to reduced success and 
learning. Research shows that the ideal level of self-efficacy is slightly above one's own ability, "which encourages people to tackle challenging tasks and gain valuable experience" (Csikszentmihalyi, 1990). When we have this balance between challenge and competence we can achieve flow.

\section{Attribution and Self-efficacy}

An attribution refers to the perceived cause of an outcome. It is a person's explanation of why a particular event turned out as it did. The explanation for fail or a good grade in an exam could be effort, skills, luck, teacher ability, or teacher inability. Weiner (1985) defines attribution in terms of three dimensions:

- Locus of causality: is the cause inside or outside the individual.

- Stability: can the cause change, e.g. illness.

- Controllability: can the individual affect the cause e.g. amount of study.

How students perceive causes in terms of these characteristics will influence self-efficacy (Seifert, 2004; Weiner, 1985). Failure caused by stable factors might lead to expectations of continued failure, which means lower self-efficacy. Failure caused by unstable factors might lead to uncertain expectations for future outcome and result in reduced self-efficacy.

Students who explain success and failure to internal, controllable causes are more likely to feel pride, satisfaction, conf idence, and have a higher self-efficacy. As a consequence these students will choose to work on more difficult tasks, persist longer in the face of failure, and produce work that is of higher quality (Seifert, 2004).

Students who explain failure to internal, uncontrollable stable factors or inability are more likely to feel shame and humiliation and will show little effort or cognitive engagement.

Students who explain success to external factors are not going to experience the self-enhancing emotions of pride, satisfaction, confidence, or self-esteem. Success explained by external factors will, therefore, not lead to more self-efficacy (Seifert, 2004).

There is a tendency in Norway to explain failure or low outcome by intelligence. In eastern countries like China or Korea, low outcome is more often explained by not spending enough effort (Garmannslund 2008). I have asked all my students, and they expla in low outcome with not spending enough effort. But if they actually fail, maybe they will have another explanation for themselves.

\section{Value and Outcome Expectations}

Motivation and self-efficacy are two very important factors for human behaviour. Outcome expectations or expected value of outcome is a third important factor. Expected value of outcome will highly influence motivation. For example students will not be motivated to work hard if they believe the outcome is of little value to them.

\section{Applying Motivational Theory to Practice}

In our department, and I will say most of our university, the use of valuable pedagogic knowledge is limited. Among our own students in IT and information systems we have experienced problems with increased dropout, low persistence, and low learning outcome. But we have only to a little extent tried to find the main reasons for this unfortunate situation. There may be many reasons for students to behave as they do, but the three constructs focused in this paper - motivation, self- 
efficacy and expected value - are important factors, and luckily factors we as a university can influence (Bandura, 1997; Linnenbrink \& Pintrich, 2002).

In this section I will present actions that are implemented on the bachelor study in IT and information systems and experience with the implemented actions. Since 2005 we have implemented several actions in order to influence motivation, self-efficacy, and value-expectation.

Through interviews of all first- and second- year students in the bachelor program in IT and Information Systems I have received valuable information. The factors that have been reported to have most influence on academic behaviour among our students are: experience success, wellbeing and confidence, lecturer's motivation and enthusiasm, learning by doing, and perceived value. These factors will influence motivation, self-efficacy, and value-expectations which finally decide student behaviour (Bandura, 1993; Csikszentmihalyi, 1990; Schunk, 2005).

\section{Experience Success}

When a person experiences success or mastery it will raise both motivation and self-efficacy. Simply put, success raises motivation and self-efficacy, failure lowers it (Schunk, 1991). Success has to be experienced on a real challenge in order to influence motivation and self-efficacy. If the task is too easy and hardly any challenge, success will hardly raise motivation and self-efficacy.

We want to increase motivation and self-efficacy among our students because this is more likely to cause them to work harder and persist longer than with low motivation and self-efficacy. High motivation and self-efficacy lead to harder work and more persistence which will lead to more success which again leads to positive influence on motivation and self-efficacy. Low motivation and low self-efficacy lead to less work, less persistence and therefore less success, which finally leads to negative influence on motivation and self-efficacy.

\section{Actions}

Among first year students there has been much focus on experiencing success. In the introductory course in IS, students have assignments that count $50 \%$ of the grade. The tasks are practical, making dynamic websites using databases and programming, including technologies like HTML, CSS, PHP and MySql. Especially among first year students there is a big variation in competence. Three years ago all students did the same assignments, which led to students finding the assignment either too easy, suitably challenging, or far too difficult. Now students design the ir own assignments, with the purpose of letting all students work with challenging assignments. Students work harder, they are more motivated when creating a small information system, and they find the practical assignments very valuable for them. "I get very motivated when I succeed. I know I will succeed in the end, it's like a game, when I work enough, I can do it" (First year student, November 2008).

A dilemma with self-selected assignments is that students have to find appropriate challenging tasks themselves. Even though students are guided by the lecturer and assistant teachers to select assignments, it may be difficult for some students to find the right level. Another dilemma is that grading is more difficult when all assignments are different, from very complex to quite simple. Since self-set assignments and self-set goals by themselves influence commitment, self-efficacy, and motivation positively (Schunk, 1991), the University can justify using self-set assignments, even when assignments count for final grading, because learning is more important than grading.

A high level of responsibility for learning is more suitable for mature students. In order to succeed with assignments students are led by the instructor and assistants in the PC-lab. Progress is made relatively slowly and the instructor explains what he is doing and why at each step. Such guidance helps students to make small increments and will positively influence motivation and self-efficacy (Margolis \& McCabe, 2006). Another advantage of this instructor led work in PC- 
lab is to have small goals along the way, instead of one big goal in the end. Proximal goals influence motivation and performance positively (Schunk, 2005).

Another issue we have discussed in our department is what to do when a large majority of the students cannot follow the progress in a course and do not understand the basic principles. One alternative is to continue as planned, to cover all themes in the syllabus. Another alternative is to reduce progress and use more time to repeat. I teach the introductory course in IS for first year students, where students learn basic IS theory and in addition some HTML, CSS, PHP and MySql. Midway in the semester I understood that many students struggled, especially with the practical part. From that day we used $50 \%$ of the lectures on repetition. Often more students meet for repetition lectures than for "normal" lectures. "In the middle of the semester it is very much new things we have to learn. For me it is necessary with repetition to catch up. I am afraid I would be far behind without it" (First year student, November 2008).

To reduce syllabus or drop lecturing some of the more advanced themes as I have done will have negative impact, especially for the stronger students. But to continue lecturing as planned when a majority of the students do not understand the basics is even worse. If a student has trouble understanding and every week there are new themes introduced building upon the themes not yet understood, this will obviously lead to reduced motivation, self-efficacy, and well-being. The serious consequence is that this negative influence on motivation, self-efficacy, and well-being takes more time to build than to reduce (Seifert, 2004).

In the introductory course in programming students have reported that the course is very difficult and quite a large number of students have failed the exam. Starting in spring 2009 there will be two lecturers having this course. Both lecturers will be present in all lectures and all lab hours. The idea is that different lecturers explain themes differently and this can give a better understanding. The lecturers are going to ask for comments during lectures and hopefully have lectures with many comments and questions, which will give more learning. The overall purpose is again to let students succeed in the programming course. In spring 2009 the department will almost double the resources spent in this course.

\section{Well-being and Confidence}

University students need to be in a social setting, they need to feel that they belong there, are accepted and valued, and have the skills and resources needed to be productive (Bowman, 2007). Learning is more difficult if you do not have friends and feel you are not part of a social community. Through my interviews with students they report well-being and confidence to be one of the most important factors for motivation to study. Students need, just as do employees in a company, to cover the more basic needs, such as confidence and well-being. We know this, but we have to be aware of this fact and to put effort in it to positively influence, since confidence and well-being will not come automatically.

\section{Actions}

The last three years we have implemented several actions to increase student confidence and well-being, especially for first year students but also for all the students in the bachelor program. For the new students we have a special scheme the first four weeks. We have only one course, called "Creative problem solving". We have very good experiences with the things we have done the two years we have had this course, 2007 and 2008. 


\section{Table 1: Actions implemented and expected outcome}

\begin{tabular}{|c|c|}
\hline Things we have done & Purpose \\
\hline $\begin{array}{l}\text { First two weeks the two lecturers meet students } \\
\text { every day }\end{array}$ & $\begin{array}{l}\text { Lecturer get "close" to students; students have } \\
\text { to be present }\end{array}$ \\
\hline Groups of eight students work daily & They learn to know several students \\
\hline $\begin{array}{l}\text { Nine compulsory assignments during the first } \\
\text { three weeks }\end{array}$ & $\begin{array}{l}\text { Force the students to work together, to estab- } \\
\text { lish appropriate learning-strategies. }\end{array}$ \\
\hline $\begin{array}{l}\text { Nine assignments are part of analysis and de- } \\
\text { sign of an IS }\end{array}$ & $\begin{array}{l}\text { Learn to work with a task they do not have the } \\
\text { prerequisite to handle. Motivate for rest of the } \\
\text { study }\end{array}$ \\
\hline $\begin{array}{l}\text { Full day lecturing in the wood, swimming, and } \\
\text { picnic }\end{array}$ & Have a good time, get to know one another \\
\hline $\begin{array}{l}\text { Lectures on motivation, self-efficacy, attribu- } \\
\text { tion etc }\end{array}$ & $\begin{array}{l}\text { Be aware of mechanisms behind own behav- } \\
\text { iour }\end{array}$ \\
\hline
\end{tabular}

There is nothing new in the actions referred to in Table 1, but it has to be done. First year students report they enjoy being students, one of the most important reasons is that they have a good time. Wellbeing and contact with the instructor is particularly important for vulnerable students. "Close contact with lecturer is very important. This is the first time I have possibility to email and meet my lecturer" "Confidence is important, then I maybe dare to ask". Or as another student said, "I feel welcome at the university, all lecturers treat us students with respect. I have studied at other universities, but I have never experienced the close contact with lecturers as here" (First year students, November 2008).

Once a month the department arranges a lunch with the students. Sometimes a local IS-company is presenting something and sometimes it is internal. The purpose is to create confidence and a feeling of belonging among the students and among students and faculty. Students report they appreciate these lunches very much, and the impression is that free food is not the most important reason. "I very much like that we are almost forced to get known to other students and that we are introduced to local IT companies" (First year students, November 2008).

The coordinator for the bachelor program in IT and Information systems has a yearly talk with all students who want to have an informal talk. Most students want this talk. I have been coordinator the last 5 years. The purpose of this talk is to get valuable information and also to talk about important issues for the department, like motivation, learning-strategies, self-regulation, our master program, etc. A side-effect, or maybe the most important effect, is that every student feels he or she is seen as special, that every student feels he or she is important for us, and that we as faculty want to have contact with them. "The best with the studies sofar is that we have close contact with lecturers, we can ask 'stupid' questions without being embarrassed. Also group work is very positive, we have to become known to several other students which is good forfeeling of being in a group" (First year student, November 2008).

\section{Lecturers' Enthusiasm and Motivation}

In fall 2007 students reported that one of the most influencing factors for motivation was the lecturers' motivation and enthusiasm (Nilsen, 2007). Enthusiasm and motivation spreads from lecturer to students and between students and their peers, either it is positive or negative. In our department we have put increased focus on this issue. Students report that lecturers communicate 
interest and enthusiasm for the subjects. "The most important for my motivation is the lecturer's enthusiasm" (Nilsen, 2007).

\section{Actions}

Several lecturers at our university now focus more on the importance of our work with student, and some of us try to have the same energy, enthusiasm, and focus on teaching as the university has on research. And we try to influence the rest of the university to have the same focus, for example, to look at teaching qualifications when the university employs new people. After all, most of our faculty use more time with student related work than on research. But we mostly employ people with a desire to do research. My impression is that most of our faculty wants more time for research and less time with students, teaching is something they have to do, we have "teaching obligations and research time". We are a group of faculty members trying to get more focus on all aspects of work with students.

The university arranges courses in university pedagogic. All new lecturers are assumed to take the course, and all other lecturers are strongly encouraged to take the course. The course has several activities, among them a one week intensive work in a monastery in Greece and to write a paper with pedagogical twist.

Another thing we have done is to have more courses with co-teaching, that is two teachers teach the same course. They do not share it - they are both present at all lectures and exercises. We have very good experience with co-teaching. Both students and lecturers report that lectures are more dynamic and have more communication and interaction.

In order to have motivated and enthusiastic faculty in teaching, we need to employ people who have the desire to teach, just as we employ people with a desire to do research. We need both since we do both research and teaching. The initiatives to have increased focus on teaching are mostly by individuals. The university's top management has to focus on this and if necessary put resources into this. An interview with me on this theme was posted at the main webpage of the university fall 2008. I have received much positive feedback: "Yes, this is important! Finally this important issue on the top agenda". Hopefully we can get increased focus on this now and make all lecturers aware of the importance we have as motivators and to inspire students.

\section{Learning by Doing}

The primary components of motivation are excitement, interest, and enthusiasm for learning (Crump, 1995). My experience is that practical work creates more excitement, interest, and enthus iasm among students than pure theory. Students report that to succeed with challenging tasks is very motivating: "The most motivating for me is to succeed with challenging tasks and hard work" (First year student, November 2008). Practical assignments are important, both for learning and motivation. "Fun to create something, to struggle and finally succeed, I learn from it and it gives me motivation. I easily get bored during lectures and reading” (Nilsen, 2007).

\section{Actions}

In many of our courses we have introduced more practical assignments. The syllabus has not changed much, the difference is the way students work in order to learn. When learning happens through assignments, it is wise to have several smaller assignments. Advice and feedback can be given frequently and progress made in small steps. As mentioned earlier, proximal goals influence motivation and performance positively (Schunk, 2005). In courses with use of the PC-lab, for example programming, database or networks, we usually have assistant teachers. In addition we now also strongly encourage the lecturer to be present in the PC-lab. 
In some courses we have given students very open projects, almost like in problem based learning (PBL). We have experienced that fresh students need more guidelines and specific projects. Our experience is that PBL is more suited for experienced and mature students.

Students report they are very satisfied with more work on practical assignments. I am convinced that students put more energy into the practical assignments, and they report they learn very much. Students also report that the practical assignments help them to better see the connection between the different subjects in our study program and also to see the purpose and value of the subjects. This understanding and awareness will in turn have a positive influence on valueexpectations and motivation on the different courses and themes.

\section{Perceived Value}

Perceived value of a task is a composite construct encompassing perceived importance, usefulness, and also interest (Bong, 2004). Perceived value is mostly positively correlated with selfefficacy and motivation. My experience is that we as lecturers have a very important role to inform students about the purpose and value of different subjects and tasks. It is both rational and logical not to put effort into something you do not see as important or valuable for yourself.

Many of the actions we have implemented will probably also influence perceived value; for example, practical assignments may give a better understanding of the purpose and value of themes like programming, databases or security.

\section{Actions}

As mentioned in the previous section, employment of theory through practical work increases the perceived value of this theory for students. When students see the purpose and can utilize a theory in a practical setting, they are more likely to see the value of this theory. Our program used to have a course in mathematics the first semester. Some of the themes here were used in the advanced database course and also in the advanced programming course, which were taught in the fourth semester. The students complained and did not see the purpose of the mathematics. Mathematics as a separate course was taken away in 2007, instead necessary mathematical themes are integrated in the courses where needed. The students now have a better understanding of the purpose and value of the mathematical themes.

The first month of the semester when first year bachelor students work full time on the course "Creative Problem Solving", the task is to work on analysis, design, and some implementation of an information system. We also work with themes like communication, cooperation, problem solving, especially where knowledge and experience are low; learning strategies. One purpose of this course is to make students aware of the need for and the value of the different courses in the bachelor program. "This course is just perfect! We were thrown into deep water. Through hard work with the project several things happened: - we got to know one another; - we understood we have to learn analysis, design, programming, database...; - and we learned how to work efficient in a group" (First year student, November 2008).

Use of guest lecturers from different companies and public organizations also helps students to see the value of what we do in our bachelor program.

After 12 years as a lecturer at the university I have experienced that one of the most important tasks for me is to sell our program, motivate and inform about the value of the different courses and themes that builds our program. Student are rational, they will have value for their effort. 


\section{Future Actions to Implement}

There are many initiatives we can do to improve learning in our study. Luckily many of these actions may be implemented in such a way that it will not involve increased costs. What I plan to do during 2009 is investigate how we can give more appropriate feedback to students and check faculty's attitudes to teaching.

\section{More appropriate feedback}

Now we use more practical assignments and we have more students because of reduced dropout. We have to admit that we give too little feedback on student work. One alternative is to use students as a resource; let students give feedback to each other. We have tried it. It is a challenge to make students put sufficient energy into evaluation and feedback of other students. Maybe we will let student's evaluation and feedback of other students influence the course grade.

\section{Faculty's attitudes to teaching}

Students report that lecturers' enthusiasm and motivation influence their own motivation. During 2009 I will explore employees motivation and self-efficacy for teaching, first at my own department and maybe expand to all of the university. Questions I will ask are: - Is teaching a task that you prioritize to do? - Do you believe you are a good teacher? - What is the value for you to do a good job with teaching?

Students who do not want to be students are probably not good students. And faculty who do not want to teach are probably not good teachers?, or what?

When we know lecturers' attitude to teaching we have to consider if there is something we should do. I believe that just to interview faculty about this and present the result among faculty will give an awareness that by itself will be of value.

\section{Summary and Results}

We know the main mechanisms behind why some students work hard with their studies while others do not. Motivation, self-efficacy, and value-expectancy are the most influencing factors on students-academic performance (Bandura, 1997; Linnenbrink \& Pintrich, 2002). Based on research, feedback from students, and my own experience the following actions are important to influence the three factors:

- Let students experience success

- Emphasize student well-being and confidence

- Increase motivation and enthusiasm among lecturers

- More learning by doing

- Make students more aware of value of content in the syllabus

Students report that they appreciate the actions we have implemented. We lecturers have also noticed that there is a positive trend among the students. The implemented actions have had a positive impact on motivation, self-efficacy, and value-expectancy. It seems like the academic performance has improved and the number of students completing our program is increasing. 


\begin{tabular}{|c|c|c|c|}
\hline Start semester & First year & Second year & Third year \\
\hline 2005 & 61 & $42 \quad(69 \%)$ & $23 \quad(37 \%)$ \\
\hline 2006 & 50 & $42 \quad(84 \%)$ & $37 \quad(74 \%)$ \\
\hline 2007 & 68 & $56 \quad(82 \%)$ & \\
\hline 2008 & 55 & & \\
\hline
\end{tabular}

Table 2 shows the positive trend in number of students, and reduced dropout the last three years. The numbers in parenthesis are percentage of active students, based on numbers of first year students. There are more reasons for reduced dropout rate than the ones discussed in this paper. But nevertheless we know from interviews that the things we have done have positively influenced students motivation self-efficacy and value-expectations. Now I look forward to investigate lecturer's attitudes to students and teaching and how we can give more appropriate feedback to students.

\section{References}

Ames, C. A. (1990). Motivation: What teachers need to know. Teachers College Record, 91(3), 409-421.

Bandura, A. (1977). Self-efficacy: Toward a unifying theory of behavioural change. Psychological Review, $64,359-372$.

Bandura, A. (1993). Perceived self-efficacy in cognitive develop ment and functioning. Educational Psychologist, 28(2), 117.

Bandura, A. (1997). Self-efficacy: The exercise of control. New York: Freeman.

Bong, M. (2004). Acade mic motivation in self-efficacy, task value, ach ievement goal orientations, and attributional beliefs. Journal of Educational Research, 97(6), 287-297.

Bowman, R. F. (2007). How can students be motivated: A misplaced question? Clearing House, 81(2), 8186.

Brewer, E. W., \& Burgess, D. N. (2005). Professor's role in motivating students to attend class. Journal of Industrial Teacher Education, 42(3), 24.

Crump, C. A. (1995). Motivating students: A teacher's challenge. Sooner Communication Conference, Norman, Oklahoma.

Csiks zentmihaly i. (1990). Flow: The psychology of optimal experience: Harper and Row.

Garmannslund, P. (2008) Course in university pedagogy, fall 2008. Internal course, University of Agder.

Honkimaki, S. P., \& Sakari, T. V. (2004). University students' study orientations, learning experiences and study success in innovative courses. Studies in Higher Education, 29(4), 431-449.

Linnenbrink, E. A., \& Pintrich, P. (2002). Motivation as an enabler for acade mic success. School Psychology Review, 31(3), 313.

Margolis, H., \& McCabe, P. P. (2006). Improving self-efficacy and motivation: What to do, what to say. Intervention in School \& Clinic, 41(4), 218-227.

Miller, K. A. (1988). Intrinsic motivation and self-determination in hu man behavior. Contemporary Sociology, 17(2), 253-253.

Moneta, G. B. (2004). The flow model of intrinsic motivation in Chinese: Cultural and personal moderators. Journal of Happiness Studies, 5(2), 181-217. 
Nilsen, H. (2006). Action research in progress: Student satisfaction, motivation and drop out among bachelor students in IT and information systems program at Agder University College, Nokobit. Nokobit: Tapir A kademisk Forlag.

Nilsen, H. (2007). Motivation and learn ing strategies of IS students: From theory to practice. Paper presented at the Computer Science and IT Education Conference, Mauritius. Retrieved from http://csited.org/2007/21NilsCSITEd.pdf

Palmer, D. (2005). A motivational view of constructivist-informed teaching. International Journal of Science Education, 27(15), 1853-1881.

Ryan, R. M., \& Deci, E. L. (2000). Intrinsic and extrinsic motivations: Classic definitions and new directions. Contemporary Educational Psychology, 25, 54-67.

Schunk, D. H. (1991). Self-efficacy and academic motivation. Educational Psychologist, 26(3), 207 - 231.

Schunk, D. H. (2005). Self-regulated learning: The educational legacy of Paul R. Pintrich. Educational Psychologist, 40(2), 85-94.

Seifert, T. L. (2004). Understanding student motivation. Educational Research, 46(2), 137-149.

Sirota, D., Mischkind, L., \& Meltzer, M. (2005). Assumptions that kill morale. Leader to Leader, 38, 24 27.

Vansteenkiste, M., Lens, W., \& Deci, E. L. (2006). Intrinsic versus extrinsic goal contents in selfdetermination theory: Another look at the quality of academic motivation. Educational Psychologist, 41(1), 19-31.

Walker, C., Greene, B., \& Mansell, R. (2006). Identification with academics, intrinsic/extrinsic motivation, and self-efficacy as predictors of cognitive engagement. Learning and Individual Differences, 16(1), 112.

Weiner, B. (1985). An attributional theory of achievement motivation and emotion. Psychological Review, $92,548-573$.

\section{Biography}

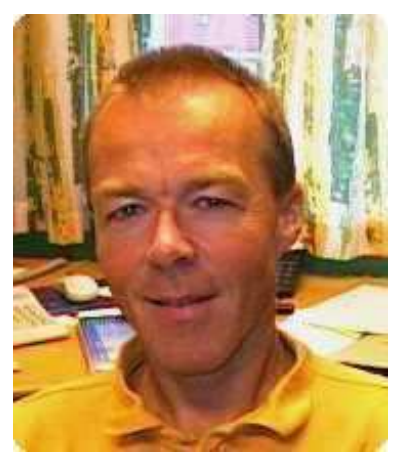

Hallgeir Nilsen is Associate Professor at University of Agder. He is Cand. Scient. in Information Systems from the University of Oslo. For ten years he worked with system development, from 1987 till 1997. In this period he was employed by the municipality of Oslo, Andersen Consulting ANS, and Allianse Informasjonssystemer. In 1997 Hallgeir started working at University of Agder. His research interests are implementation and use of ICT in public sector, end-user-training, how to teach information systems and how to create enthusiasm for learning. 